\title{
The Influence of Social Media Marketing, Institutional Image and Trust on Student Loyalty
}

\author{
Dewi Murtiningsih ${ }^{1}$, Brury Trya Sartana ${ }^{2}$, Darmawan Napitupulu ${ }^{3}$ \\ \{dewi.murtiningsih@budlihur.ac.id ${ }^{1}$, brury@budiluhur.ac.id², darwan.na70@gmail.com ${ }^{3}$ \} \\ ${ }^{1}$ Fakultas Ekonomi dan Bisnis, Universitas Budi Luhur, Jl. Ciledug Raya, Jakarta, Indonesia \\ ${ }^{2}$ Fakultas Teknologi Informasi, Universitas Budi Luhur, Jl. Ciledug Raya, Jakarta, Indonesia \\ ${ }^{3}$ Pasca Sarjana, Universitas Budi Luhur, Jl. Ciledug Raya, Jakarta, Indonesia
}

\begin{abstract}
The purpose of this research is to find out the influence of social media marketing on student loyalty, to find out the influence of social media marketing on institutional image, to find out the influence of institutional image on student loyalty, to find out the influence of social media marketing on student loyalty through institutional image, to find out the influence of social media marketing on trust, to find out the influence of trust on student loyalty, to find out the influence of social media marketing on student loyalty through trust, to find out the influence of (institutional) image on trust. This research is categorized as explanatory research. The population is bachelor degree students (S1) of five faculties at Budi Luhur University Jakarta who are at least already on their 4th semester. The data is collected using questionnaire which reliability and validity are tested for 30 respondents. The research sample is using purposive sampling with total of 110 respondents. The data is analyzed using Structure Equation Modeling (SEM) which consists of measurement model and structural model of AMOS program. Based on the research result, it can be concluded that social media marketing influences student loyalty, social media marketing influences institutional image, institutional image influences student loyalty, competitive advantage does not mediate the influence of social media marketing on student loyalty, social media marketing does not influence trust, trust influences student loyalty, and institutional image and trust do not mediate the influence of social media marketing on student loyalty.
\end{abstract}

Keywords: Social Media Marketing, Institutional Image, Trust, Student Loyalty.

\section{Introduction}

The concept of loyalty in marketing is an important study. According to (Hennig-Thurau, et al., 2001) customer loyalty extensively accepted as the main factor that helps companies to reach long term success. Therefore, in marketing context, consumer loyalty is the main goal of companies to achieve. (Hennig-Thurau, et al., 2001) in their research mentions that a student who is loyal to his university supposedly not only taking advantage of the institution but also have to have feeling and positive attitude cognition towards the institution as the basic motivation to behave. In other word, student loyalty supposedly not only giving advantage or benefit for university at the time of their active study at campus but also bigger benefit after their graduation.

One of the important factors to support the process is by using information technology tool such as social media, in this case the utilization of social network at university (Sensus and Napitupulu, 2017) aside from its function as a means to promote product, social media can also be used as a means to interact with consumers. Through a frequently repeated advertisement, update status both information such as announcement, achievements and activity documentation, at least product promotion will be noticed by consumers. 
This research reconstructs the previous research conducted by (Erdogmus, and Cicek, 2012) entitled the influence of social media marketing on brand loyalty. However, this research adds image and trust as mediation variable. Considering the indirect influence of social media marketing on loyalty through image mediation variable which is not yet observed by many researchers, and the previous research on both direct and indirect influence was frequently conducted in manufacturer company, thus this research is conducted in university.

The research result of (Erdogmus and Cicek, 2012) shows that social media marketing influences brand loyalty, while the research conducted by (Schivinski et al, 2013) states that marketing communication in social media does not influence consumer's interest of a brand. This inconsistent research result thus creates research gap (Napitupulu, et al, 2018; Rachman, and Napitupulu, 2018). The research result of (Murtiningsih and AliMurad, 2016) states that brand trust influences brand loyalty. The research conducted by (Bastian, 2014) shows the same result. The research by (Lau and Lee, 1999; Delgado et al, 2005) described that customer loyalty is the main activator of loyalty. The influence of customer trust on customer loyalty studied by (Morgan, and Hunt, 1994)proves that trust will create a positive relation with repeated intention and also loyalty. Moreover, the research done by (Handayani, and Martini, 2015)shows that brand trust influences brand loyalty.

The research result of (Wijaya and Putri, 2013)shows that activities in social media influences the brand image of university. In the research, it explains that the role of social media is very strong in establishing brand image, moreover social media also have role in increasing the brand image of the university. The research result of (Wijaya and Putri, 2013) indicates that the strongest influencer of brand image is shown by community and connectivity role.

The research result of (Pramudyo, 2012; Arwanda et al, 2014; Nurfaizal et al, 2015) shows that image influences loyalty. It is proved by the like and trust feelings shown by the students towards the university where they study. The joyous feeling felt by the students was formed after visiting and studying at the university. This fancy experience therefore becomes their reason to recommend it to other people. Of course it cannot be separated from the effort of the university to continuously create positive image. The research result of Tingkir (2014) proves that brand image influences brand loyalty, and the research result of (Handayani and Martini, 2015)shows that brand image positively influences brand trust. Brand image which is positively perceived by consumer can also influence the formation of positive brand loyalty.

The research result of (Mosavi, and Kenarehfard, 2013a; 2013b) on Samsung and Apple cell phone Company shows that social media marketing influences trust. Social media is a tool used to enhance customer trust that will influence the decision to buy a product.

The research result of (Handayani and Martini, 2015) points that brand image positively influences brand trust, and so does the research result of (Tingkir, 2016). The better the brand image created by a company, the better the brand trust in the consumer's point of view.

The difference between this research and the previous is: the object of the previous research is limited only in manufacturer and it tests brand image as independent variable that directly influences loyalty, while in this research, brand image have role as mediation variable. Moreover, the targeted respondents of this research are students of Budi Luhur University Jakarta who are at least already on their 4th semester.

The research conducted by (Erdogmus and Cicek, 2012; Murtiningsih and Murad, A., 2016) shows that social media marketing influences brand loyalty. Moreover, the influence of social media marketing on brand loyalty can draw more attention from academic marketing and practitioner in marketing field (Kaplan, A M., and Haenlein, 2009; Coon, 2010; McKee, 2010). Based on the opinion above, therefore the hypothesis is: 


\section{$\mathrm{H}_{1}$ : Social media marketing influences loyalty.}

Based on the research result of Rizal (2014), it shows that Twitter social media marketing strongly influences the formation of brand image of Restoran Burger Gabooh Pekanbaru. Furthermore, the research conducted by (Roslina, 2010) shows that brand image is formed by various brand identity elements, with advertisement as one of the most important media in giving information to consumers and placing the brand in the consumer's mind. Based on the theory, it can be concluded that social media marketing influences image. Therefore, based on the opinion, the hypothesis is:

$\mathrm{H}_{2}$ : Social media marketing influences image.

Based on the research result of (Martensen et al., 2000) it shows that institutional image influences customer loyalty. Moreover, according to the research result of (Soneta, 2009) it shows that supermarket image influences customer loyalty. Other research result of (Martensen et al, 2000) indicates that institutional image influences customer loyalty. (Abdullah, Al-Nasser, Husain, 2007) also conducted research and it shows that customer loyalty is influenced by service image. Based on the opinion, therefore the hypothesis is:

$\mathrm{H}_{3}$ : Image influences loyalty.

Based on the concept and the result of the previous research conducted by (Martensen et al, 2000; Abdullah et al, 2007; Soneta, 2009; Erdogmus, 2012; Murtiningsih et al, 2016), the purpose of this research is to find out whether social media marketing through image influences loyalty. Based on the explanation above, therefore the hypothesis is:

$\mathrm{H}_{4}$ : Social media marketing influences loyalty through image.

The result of the research by (Mosavi and Kenarehfard, 2013a; 2013b); (Etemadifard et al, 2013) shows that social media marketing influences brand trust. Social media is a communication and sharing tool that will influence the consumer's decision in buying a product or service if there is trust. Based on this opinion, therefore the hypothesis is:

$\mathrm{H}_{5}$ : Social media marketing influences trust.

The research of Chow and Holden (1997) was intended to see the linkages between trust and loyalty shows that trust positively and strongly influences loyalty. The research result of (Bastian, 2014) also proves that trust influences loyalty. Based on this opinion, therefore the hypothesis is:

$\mathrm{H}_{6}$ : Trust influences loyalty.

Based on the research concept by (Mosavi, S.A., and Kenarehfard, 2013a ; 2013b); (Chow et al, 1997; Etemadifard et al, 2013; Bastian, 2014) therefore the purpose of this research is to find out whether social media marketing influences loyalty through trust. Thus, the hypothesis of this research is:

H7: Social media marketing influences loyalty through trust.

The research result of (Lau, 1999) shows that brand image helps in developing consumer's trust. Based on this concept, therefore the hypothesis is:

$\mathrm{H}_{8}$ : Image influences trust

\section{Research Methodology}

This research is categorized in explanatory research. The observed object in this research is social media marketing, customer relationship management, competitive advantage, and student loyalty variables, and the research subject is bachelor degree students (S1) of five faculties at Budi Luhur University Jakarta who are at least already on their $4^{\text {th }}$ semester. Research sample is determined to be 100 plus $10 \%$, therefore the total sample (n) is 110 students. It is determined with consideration that if there are some invalid samples during the collection of the questionnaire, the rest of it will still be able to fulfill the principle of 
minimum sample measurement. This research uses analysis model Structure Equation Model (SEM) with AMOS (Analysis of Moment Structure) application.

\section{Result \& Discussions}

The data analysis technique using Structure Equation Modelling (SEM) with Analysis of Moment Structures (AMOS) application is used to analyze the causal relationship between social media marketing, image, trust and student loyalty.

The theoretical model of the research conceptual frame is said to be fit if it is supported by empirical data. The test result of goodness of fit overall model is used to find out whether hypothetical model is supported by empirical data. Goodness of fit model shows that $\mathrm{X}^{2} / \mathrm{df}=$ 2.784; GFI $=0.558 ; \mathrm{CFI}=0.537 ; \mathrm{TLI}=0.499 ; \mathrm{PGFI}=0.484 ; \mathrm{RMSEA}=0.128$, since the value of goodness of fit indices has not fulfill the requirement yet, therefore model modification is needed to be done to evaluate the value of loading factor. Modification 1: erasing indicators SoBA12, DC11, DC12, MLB12, SoBA11, UoBA12, AR12,MLB12, BM12, UoBA11, MSC11, because the loading factor is below $0.5 \mathrm{X}^{2} / \mathrm{df}=2.830 ; \mathrm{GFI}=0.644 ; \mathrm{CFI}=$ $0.685 ; \mathrm{TLI}=0.642 ; \mathrm{PGFI}=0.517 ; \mathrm{RMSEA}=0.130$. Modification 2: correlating e1-e2 and e7$\mathrm{e} 8 ; \mathrm{X} 2 / \mathrm{df}=2.269 ; \mathrm{GFI}=0.692 ; \mathrm{CFI}=0.784 ; \mathrm{TLI}=0.751 ; \mathrm{PGFI}=0.550 ; \mathrm{RMSEA}=0.108$. Modification 3: correlating e3-e4, and erasing AOSM 12, MLB11, MSC12 because the loading factor is below 0.5 . $\mathrm{X} 2 / \mathrm{df}=2.136$; GFI $=0.766$; $\mathrm{CFI}=0.844$; $\mathrm{TLI}=0.814$; PGFI $=$ $0.576 ;$ RMSEA $=0.102$. Modification 4: correlating e27-e28; X2/df $=1.998 ; \mathrm{GFI}=0.783$; $\mathrm{CFI}=0.864 \mathrm{TLI}=0.837 ;$ PGFI $=0.585 ;$ RMSEA $=0.096$. Modification 5 : erasing RC 1 and $\mathrm{RC} 2$ because the high $\mathrm{MI} ; \mathrm{X} 2 / \mathrm{df}=1.692 ; \mathrm{GFI}=0.836$; $\mathrm{CFI}=0.906 \mathrm{TLI}=0.884$; PGFI $=$ $0.601 ;$ RMSEA $=0.080$

The result of CFA shows that the model can be categorized as fit because the value of normed square, RMSEA, PGFI and TLI is already above the cut-off value. Meanwhile, the value of GFI and CFI is already approaching (Hair et al.2016). The test result of goodness of fit overall model can be seen in the Figure and Table below.

Table 1. Test Result of Goodness of Fit Overall Model.

\begin{tabular}{llll}
\hline $\begin{array}{l}\text { Goodness of } \\
\text { fit index }\end{array}$ & Cut off Value & Model Result & Remarks \\
\hline Chi-Square & Expected small & 186,134 & Bad Fit \\
\hline Probabilitas & $\geq 0.05$ & 0,000 & Fit \\
\hline CMIN/DF & $\leq 2.00$ & 1,692 & Fit \\
\hline GFI & $\geq 0.90$ & 0,836 & Marginal \\
\hline AGFI & $\geq 0.90$ & 0,756 & Bad Fit \\
\hline PGFI & $\geq 0.90$ & 0,601 & Bad Fit \\
\hline TLI & $\geq 0.95$ & 0,884 & Marginal \\
\hline CFI & $\geq 0.90$ & 0,906 & Fit \\
\hline RMSEA & $\leq 0.08$ & 0,080 & Fit \\
\hline
\end{tabular}

Based on the test result of goodness of fit overall on Table 1 above, it can be seen that only four out of eight criteria that fulfill the requirement. According to Arbuckle and Wothke, in (Solimun, 2002) the criteria used to indicate a good model is Chi Square/DF which is less than 2, and RMSEA which is below 0.08. In this research, the value of CMIN/DF and RMSEA fulfilled the cut off value. Therefore, the SEM model in this research is fit and feasible to be used, and thus interpretation can be done for further discussion. 
The test result of loading factor value shows that there is no problem found related to the validity of convergent because each indicator already have loading factor value above 0.5 (Ghozali, 2009).

Table 2. Standardized Regression Weights.

\begin{tabular}{llll}
\hline & & & Estimate \\
\hline AC1 & $<---$ & SosmedMktg &, 594 \\
\hline AC2 & $<---$ & SosmedMktg &, 579 \\
\hline PC11 & $<---$ & SosmedMktg &, 689 \\
\hline PC12 & $<---$ & SosmedMktg &, 734 \\
\hline VP11 & $<---$ & SosmedMktg &, 676 \\
\hline VP12 & $<---$ & SosmedMktg &, 622 \\
\hline FoBA12 & $<---$ & Image &, 702 \\
\hline FoBA11 & $<---$ & Image &, 873 \\
\hline AWI12 & $<---$ & Trust &, 791 \\
\hline AWI11 & $<---$ & Trust &, 571 \\
\hline AR11 & $<---$ & Trust &, 675 \\
\hline MS11 & $<---$ & Loyalty &, 602 \\
\hline BM11 & $<---$ & Loyalty &, 747 \\
\hline MS12 & $<---$ & Loyalty &, 693 \\
\hline AOSM11 & $<---$ & SosmedMktg &, 651 \\
\hline MC11 & $<---$ & Loyalty &, 515 \\
\hline MC12 & $<---$ & Loyalty &, 565 \\
\hline
\end{tabular}

The Problem related to discriminant validity is not found. It is because the correlation value of each variable is below 0.85 (Hair et al, 2006).

Table 3. Correlations.

\begin{tabular}{llll}
\hline & & & Estimate \\
\hline SosmedMktg & $\langle-->$ & Image &, 498 \\
\hline SosmedMktg & $<-->$ & Trust &, 160 \\
\hline SosmedMktg & $<-->$ & Loyalty &, 745 \\
\hline Image & $<-->$ & Trust &, 004 \\
\hline Image & $<-->$ & Loyalty &, 675 \\
\hline Trust & $<-->$ & Loyalty &, 489 \\
\hline e1 & $<-->$ & e2 &, 713 \\
\hline e7 & $<->$ & e8 &, 626 \\
\hline e27 & $<->$ & e28 &, 485 \\
\hline
\end{tabular}

Based on the reliability analysis, it can be seen that all constructs have good reliability. It is because each construct have composite reliability/Cronbach Alpha value above 0.7.

Table 4. Cronbach Alpha.

\begin{tabular}{lc}
\hline Variable & Cronbach Alpha Value \\
\hline SMM & 0,876 \\
\hline
\end{tabular}




\begin{tabular}{ll}
\hline Image & 0,833 \\
\hline Trust & 0,868 \\
\hline Student Loyality & 0,841 \\
\hline
\end{tabular}

Table 5 below shows that out of six direct influences between variables that are tested, there are four that have significant influence and the other two are insignificant. Social media marketing variable significantly influences loyalty variable; social media marketing insignificantly influences trust variable; social media marketing variable significantly influences image variable; image variable significantly influences loyalty variable; trust variable influences loyalty; and image variable insignificantly influences trust variable.

Table 5.Structural Model of SEM Result; Direct Influence.

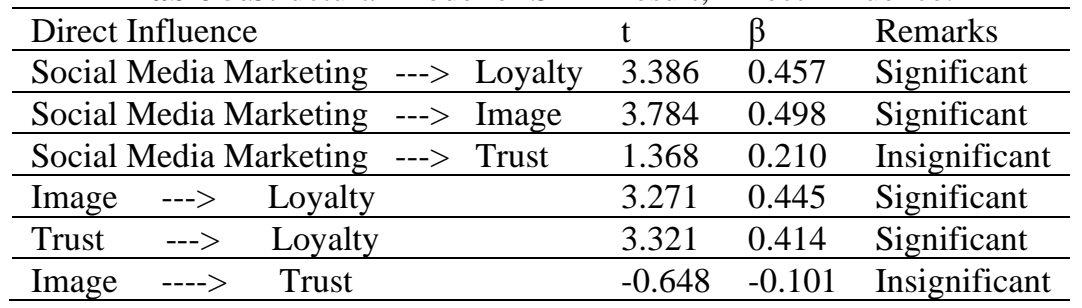

After conducting direct influence test, the next step is to conduct indirect influence test by using mediation test on image and trust variable in mediating the influence of social media marketing on loyalty. Table below presents the result of the mediation test:

Table 6. Result of Mediation Test using Sobel Test.

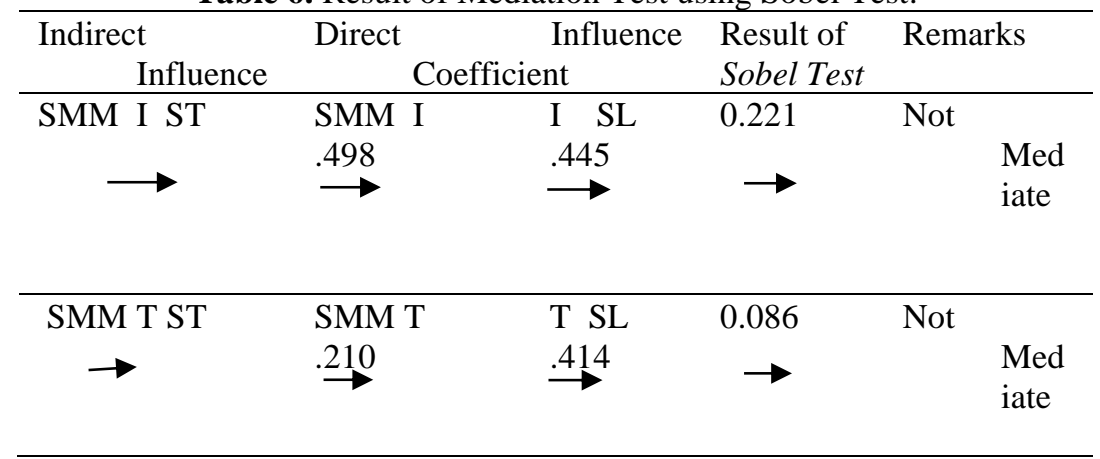

The analysis result of the influence of social media marketing on loyalty on Table 5 shows that social media marketing directly influences loyalty. The coefficient of direct influence of social media marketing on brand loyalty is 0.457 . This research shows that the higher the intensity of social media marketing usage, the higher the value of loyalty. In contrary, the lower the intensity of social media marketing usage, the lower the value of loyalty Coefficient with positive mark shows that there is a direct relationship between social media marketing and loyalty. It shows that there is adequate empirical evidence to accept hypothesis one (H1). The empirical fact shows that the indicator of social media marketing which is popular content in form of every status updated at university where I study in social media such as Facebook and Twitter; catchy and trending promotion sentence used by 
university in social media like Facebook and Twitter, are already well-perceived by respondents. This research result shows that it is in line with the research conducted by (Erdogmus and Cicek, 2012; Murtiningsih and Murad, 2016) and (Mehrabi et al, 2014).

The analysis result of the influence of social media marketing on image on Table 5 shows that social media marketing directly influences image. The coefficient of the direct influence of social media marketing usage intensity on brand loyalty is 0.498 . It means that the higher the intensity of social media marketing usage, the higher the value of image. In contrary, the lower intensity of social media marketing usage the lower the value of image will be. Coefficient with positive mark shows that there is direct relationship between social media marketing and image. This indicates that there is adequate empirical evidence to accept hypothesis two (H2). The empirical fact shows that the indicator of social media which is popular content in form of every status updated at university where I study in social media such as Facebook and Twitter; catchy and trending promotion sentence used by university in social media like Facebook and Twitter, are already well-perceived by respondents that it will be able to influence the institutional image of Budi Luhur University Jakarta. This research result shows that it is in line with the research conducted by (Rizal, 2014; Sitepu and Kumadji, 2015)

The analysis result of the influence of image on loyalty on Table 5 shows that image directly influences loyalty. The coefficient of the direct influence of image on loyalty is 0,101 . This research indicates that the higher the intensity of image usage, the higher the value loyalty. In contrary, the lower the intensity of image usage, the lower the value of loyalty will be. Coefficient with negative mark shows that there is indirect relationship between image and loyalty. This shows that there is adequate empirical evidence to accept hypothesis three (H3). The empirical fact shows that the indicator of image which is favorability of brand advantage in form of the availability of various scholarships offered by the university where I study and the facility given by the university in paying the tuition, are already well-perceived by respondents that it will be able to influence the student loyalty toward the institution, in this case Budi Luhur University Jakarta. The result of this research is in line with the research conducted by (Andreassen et al, 1998; Martensen et al, 2000; Abdullah et al, 2007).

The analysis result of the influence of social media marketing on loyalty through image on Table 6 shows that image does not mediate the influence of social media marketing on loyalty. The coefficient of direct influence of social media marketing on brand loyalty is 0.498 and the direct influence of image on loyalty is 0,445 , while the value of indirect influence of social media marketing on loyalty through image is 0,221 . This research shows that image variable does not have role in mediating the influence of social media marketing on loyalty. This shows adequate empirical evidence not to accept hypothesis four (H4).

The analysis result of the influence of social media marketing on trust on Table 5 shows that social media marketing indirectly influences trust. The coefficient of direct influence of social media marketing on trust is 0.210 . This research indicates that the higher the intensity of social media marketing usage, the higher the value of trust. In contrary, the lower the intensity of social media marketing usage, the lower the value of trust will be. Coefficient with positive mark shows that there is direct relationship between social media marketing and trust. This shows that there is adequate empirical evidence to accept hypothesis five (H5). The empirical fact shows that the indicator of social media marketing which is popular content in form of every status updated at university where I study in social media such as Facebook and Twitter; catchy and trending promotion sentence used by university in social media like Facebook and Twitter, are not well-perceived by respondents, therefore it is not able to influence student 
trust in Budi Luhur University Jakarta. This research result shows that it research is not in line with the research conducted by (Mosavi, S.A., and Kenarehfard, 2013a; 2013b).

The analysis result of the influence of trust on loyalty on Table 5 shows that trust directly influences loyalty. The coefficient of direct influence of trust on loyalty is 0.414 . This research indicates that the higher the intensity of trust usage, the higher the value of loyalty. In contrary, the lower the intensity of trust usage, the lower the value of loyalty will be. Coefficient with positive mark shows that there is direct relationship between trust and loyalty. This shows that there is adequate empirical evidence to accept hypothesis six (H6). The empirical fact shows that the indicator of trust which is acting with integrity, in form of the politeness shown by the teaching staff and also employees of the university, and the ability of the university to provide comfort during the learning process are already well-perceived by the respondents that it will be able to influence the student loyalty in Budi Luhur University Jakarta. This research result shows that it is in line with the research conducted by (Selnes, 1998).

The analysis result of the influence of social media marketing on loyalty through image on Table 6 indicates that trust does not mediate the influence of social media marketing on loyalty. The coefficient of direct influence of social media marketing on image is 0.210 and direct influence of trust on loyalty is 0.414 , while the value of indirect influence of social media marketing on loyalty through image is 0.086 . This result means that trust variable does not have role in mediating the influence of social media marketing on loyalty. It shows that there is adequate empirical evidence not to accept hypothesis seven (H7).

The analysis result of the influence of trust on loyalty on Table 4.5 shows that trust directly influences loyalty. Coefficient of direct influence of trust on loyalty is 0.414 . This result means that the higher the image, the higher the value of trust. In contrary, the lower the intensity of trust usage, the lower the value of loyalty will be. Coefficient with positive mark indicates that there is direct relationship between trust and loyalty. This shows that there is adequate empirical evidence to accept hypothesis eight (H8). The empirical fact shows that the indicator of image variable which is brand advantage (Favorability of Brand Association) in form of the various scholarships offered by the university where I study is already wellperceived by the respondents, especially the students of Budi Luhur University Jakarta. Meanwhile, for item the university where I study provides facility in paying the tuition still needs more attention. This research result shows that it is in line with the research conducted by (Lau, 1999).

Recommendation of this research is for the administrator of private universities in Jakarta to focus more in observing the social media marketing by understanding the application of popular content in various social media used. Dominant contribution in reflecting image variable that is the item Budi Luhur Univeristy Jakarta provides facility for the students, is not yet well-perceived by the respondents. Thus, the administrator of Budi Luhur Univeristy should give more attention in fulfilling the students' need such as providing facility for students to pay their school fee, while in the other hand, keep trying to increase the favorability of brand association. Achieving result (fulfilling promise to the students) has an important contribution in reflecting trust and it still needs to be improved. The administrator of Budi Luhur University also need to provide facility for students to process the study card plan (KRS) online, such as minimized network trouble during the online study card plan process. Budi Luhur University is a commercial institution in education field, therefore it is expected that the administrators are more intense and optimal in utilizing the usage of social media marketing in promoting the university. 
This research focuses on the influence of social media marketing on student loyalty with the mediation of image and trust with no regard to other variable, thus other variables such as service quality, brand equity, brand awareness are needed to find out the intensity social media marketing utilization on brand loyalty. Further research is expected to add more samples and also broaden the research object that relevant to the research topic.

\section{Conclusion}

Based on the discussion result, contribution and research result findings, the configuration of conceptual frame as in the research model, then the conclusion of the research can be specifically drawn as follow: Social media marketing can directly influence the enhancement of student loyalty. Social media marketing can influence the enhancement of institutional image. A better institutional image can influence the enhancement of loyalty. Apparently, image does not have role in mediating the influence of social media marketing on student loyalty. Social media marketing is not yet able to influence the enhancement of trust. Apparently, trust is able to influence the enhancement of student loyalty. Trust does not have role in mediating the influence of social media marketing on the enhancement of student loyalty. Image is able to influence the enhancement of trust.

\section{Acknowledgement}

We would like to thank the research institution that has supported the research activities was being carried out properly.

\section{Reference}

[1] Abdullah, Al-Nasser, Husain (2007) 'Pengaruh Citra terhadap Loyaitas pelanggan.'

[2] Andreassen, T.W. and Lindestad, B. (1998) 'Customer loyalty and complex services: the impact of corporate image on quality, customer satisfaction and loyalty for customers with varying degrees of service expertise.', International Journal of Service Industry Management, 9(1), pp. 7-23.

[3] Arwanda, Nur Oktavia Dwine, Hartoyo, S. (2014) 'Kepuasan, Citra dan Loyalitas Pada Lembaga Pendidikan Tinggi: Kasus Di Akademi XYZ.', Jur. Ilm. Kel. \& Kons., 7(2), pp. 123-132.

[4] Bastian, D. A. (2014) 'Ananlisis Pengaruh Citra Merek (Brand Image) dan Kepercayaan Merek (Brand Trust) Terhadap Loyalitas Merek (Brand Loyalty) ADES PT. Ade Alfindo Putra Setia.', Jurnal Manajemen Pemasaran Petra., 2(1), pp. 1-9.

[5] Chow, Simeon, Reed, H. (1997) 'Toward An understanding Of Loyalty The Moderating Role of Trust”.', Journal of Managerial Issues, 9(3).

[6] Coon, M. (2010) 'Social Media Marketing: Successful Case Studies of Businesses Using Facebook and YouTube With An In-Depth Look in the Business Use of Twitter.', Communication M.A. Project. Available at: source: http://comm.stanford.edu/coterm/projects/2010/maddy coon.pdf (accessed on 02 March 2012).

[7] Delgado-Ballester, E., Munuera-Aleman, J L. (2005) 'Does Brand Trust Matter to Brand Equity?', Journal of Product and Brand Management, 14(3), pp. 87-196.

[8] Erdogmus, I and Cicek, M. (2012) 'The impact of social media marketing on brand loyalty.', in Procedia - Social and Behavioral Sciences, 58, pp. 1353-1360.

[9] Etemadifard, M., Kafashpoor, A., Zendehdel, A. (2013) 'The Effect of Brand 
Communication and Service Quality in the Creation of Brand Loyalty through Brand Trust (Case Study: Samsung's Representatives Company in Mashhad City).', International Journal of Advanced Studies in Humanities and Social Science, 1(8), pp. 1067-1077.

[10] Ghozali, I. (2009) Aplikasi Analisis Multivariate Dengan Program SPSS,. Edisi Keem. Edited by P. U. Diponegoro. International, Inc.

[11] Hair, J.F., Black, W.C., Babin, B.J., Andressen, R.E., dan Tatham, R. L., . (2006) Multivariate Data Analysis 6th Edition. New Jesey: Perason Prentice Hall.

[12] Handayani, S.M., and Martini, I. (2015) 'Pengaruh Brand Image Terhadap Brand Loyalty Brand Trust Sebagai Variabel Mediasi.', in Managemen Dynamics Conference. Semarang.

[13] Hennig-Thurau, et al. (2001) 'Modeling and Managing Student Loyalty: An Approach Based on the Concept of Relationship Quality.', Journal of Service Research, 3(4), pp. 331-345.

[14] Kaplan, A M., and Haenlein, M. (2009) 'The Fairyland of Second Life: Virtual Social Worlds and How to Use Them. Business Horizons.' Available at: http://www.michaelhaenlein.com/Publications/Kaplan,pdf.

[15] Lau, G. . and L. S. H. (1999) 'Consumers Trust In a Brand and The Link To Brand Loyalty.', Journal of Market Focused Management, 4, pp. 341-370.

[16] Martensen, Gronholdt, Eskildsen, K. (2000) 'Benchmarking Student Satisfaction in Higher Education Base on The ECSI Methodology. Sinergie.’, p. 385-402.

[17] McKee, S. (2010) Creative B2b Branding (No, Really): Building a Creative Brand in a Business World. USA: Goodfellow Publishers Limited.

[18] Mehrabi, A., Islami, H., Aghajani, M. (2014) 'The Effect of Social Media Marketing on Customers' Brand Loyalty', International Journal of Academic Research in Business and Social Sciences, 4(8), pp. 480-495.

[19] Morgan, R M., Hunt, S. D. (1994) 'The Commitment-Trust Theory of Relationship Marketing.', Journal of Marketing, 58(3), pp. 20-38.

[20] Mosavi, S.A., and Kenarehfard, M. (2013) 'The Impact of Value Creation Practices on Brand Trust and Loyalty in a Samsung Galaxy Online Brand Community in Iran.', IJMM Winter, 8(2), pp. 75-84.

[21] Mosavi, Seyed Alireza, Kenarehfard, M. (2013) 'The Effect of Value creation practices on brand trust and brand loyalty: Case study of Apple Iphone cell phone, Shiraz, Iran.', Prime Journal of Business Administration and Management (BAM), 3(9), pp. 11821189.

[22] Murtiningsih, D., AliMurad, A. (2016) 'The Effect of Social Media Marketing to Brand Loyalty (Case Study at the University Budi Luhur Jakarta).', International Journal of Business and Management Invention (IJBMI), 5(2), pp. 50-53.

[23] Napitupulu, D., Rahim, R., Abdullah, D., Setiawan, M I., Abdillah, L., Ahmar, A S., Simarmata, J., Hidayat, R., Nurdiyanto, H., Pranolo, A. (2018) 'Analysis of Student Satisfaction Toward Quality of Service Facility.', J. Phys. Conf. Ser, 954(1), p. 12019.

[24] Nurfaizal, Yusmedi, Pinilih, M. (2015) 'Analisis Citra, Kepercayaan Dan Kepuasan Terhadap Loyalitas Mahasiswa Sistem Informasi Dengan Pendekatan Path Analisys.', Journal Informatika AMIK-LB, 3(3), pp. 106-115.

[25] Pramudyo, A. (2012) 'Pengaruh Citra Merek Terhadap Loyalitas Melalui Kepuasan Sebagai Intervening.', JBMA, 1(1), pp. 1-16.

[26] Rachman, T., Napitupulu, D. (2018) 'User Acceptance Analysis of Potato Expert System Application Based on TAM Approach.', International Journal Adv. Sci. Eng. 
Inf. Technology, 8(1), pp. 185-191.

[27] Rizal, V. Z. (2014) 'Pengaruh Social Media marketing Twetter terhadap Pembentukan Brand Image Restoran Burger Gaboh PekanBaru.', Jurnal Ilmu Komunikasi, 5(1), pp. 1-118.

[28] Roslina, et. al. (2010) 'Jurnal Bisnis \& Manajemen: Bandar Lampung: Universitas Lampung.', 6(3).

[29] Schivinski, Bruno, Dabrowski, D. (2013) 'The Effect of Social - Media Communication on Customer Perceptions of Brands.', GUT Faculty of Management and Economics, 4, p. 2-20.

[30] Selnes, F. (1998) 'Antecedents and Consequences of Trust and Satisfaction in BuyerSeller Relationship', Journal of Marketing, 32(3/4), pp. 305-322.

[31] Sensuse, D I., and Napitupulu, D. (2017) 'The Study of User Acceptance Toward ELearning System in Higher Education.', International Journal of Electrical Engineering and Computer Science, 7(2), pp. 466-473.

[32] Sitepu, R. D. and Kumadji, S., W. (2015) 'Pengaruh Marketing Public Relation Terhadap Brand Image dan Loyalitas Pelanggan (Survei Pada Wisatawan Taman Rekreasi Selecta, Batu)', in. Fakultas Ilmu Administrasi Universitas Brawijaya Malang.

[33] Solimun (2002) Structural Equation Modelling (SEM) Lisrel dan AMOS”. Cetakan I. Penerbit Universitas Negeri Malang.

[34] Soneta (2009) 'Hubungan Citra terhadap loyalitas Pelanggan.'

[35] Tingkir, C. F. (2016) 'Pengaruh Identitas Merek Terhadap Loyalitas Merek Melalui Citra Merek dan Kepercayaan Merek Toyota', Jurnal Pemasaran. doi: https://doi.org/10.9744/pemasaran.8.2.62-69.

[36] Wijaya, B.S., and Putri, D.M. (2013) 'Is Social Media Impactful For University's Brand Image.', Jurnal Manajemen Teknologi, 12(3). Available at: http//dx.doi.org/10.12695/jmt. 